\title{
POTENSI AGRIBISNISUSAHATERNAK AYAM BROILER DI KOTA KENDARI
}

\author{
La Ode Arsad Sani ${ }^{\left.{ }^{*}\right)}$ Hj. Nuraini ${ }^{1)}$ dan Muhammad Diwan ${ }^{2)}$ \\ ${ }^{1)}$ Dosen Jurusan Peternakan FPT UHO \\ ${ }^{2)}$ Alumnus Jurusan Peternakan FPT UHO \\ Email : arsadni@yahoo.com
}

\begin{abstract}
The aims of this research are to analyze the channels and marketing institution, to know part of price is accepted by broiler farmer and marketing institution, to analyze the rate of marketing margin of broiler farmer, the rate of marketing institution and consumer with the rate of broiler farmer income. The research material is a good broiler farmer miter or not miters to the company with production capacity between 2.500 to 4.000 tails. The method of the research is survey research. While to determine the location of this research by using purposive sampling and took 35 respondents consisted 5 broiler farmers and 30 intermediary traders by using purposive. Tabulation data was obtained and analyzed by marketing margin and the rate of broiler farmer income were elaborated on descriptive manner. The result showed that the broiler marketing channel at Kendari City involved 4 types with two marketing institutions involved: trader collector and trader retailer, the part of price received by broiler farmer from the last consumer was $68,8 \%$ whereas the part of price received by marketing institutions was $31,2 \%$, marketing margin on the broiler price from broiler farmer to the last consumer was Rp.14.150 tails ${ }^{-1}$ (the sale of broiler in the level of broiler farmer was Rp.31.200 tails ${ }^{-1}$, broiler farmer to the trader collector was Rp. 9.000 tails $^{-1}$ and trader collector to retailers was 5.150 tails $^{-1}$ ) and the rate of the broiler farmer income in Kendari City was Rp.17.046.139 cycle ${ }^{-1}$ or Rp.5.013 tails $^{-1}$ cycle $^{-1}$.
\end{abstract}

Key words: Marketing, Income, Broiler, Marketing Margin

\begin{abstract}
ABSTRAK
Tujuan penelitian ini adalah untuk menganalisis lembaga saluran dan pemasaran, untuk mengetahui bagian dari harga yang diterima oleh petani broiler dan lembaga pemasaran, untuk menganalisis tingkat marjin pemasaran petani broiler, tingkat lembaga pemasaran dan konsumen dengan tingkat pendapatan petani broiler.. Bahan penelitian adalah baik petani broiler mitra atau tidak miter untuk perusahaan dengan kapasitas produksi antara 2,500-4,000 ekor. Metode penelitian ini adalah penelitian survei. Sedangkan untuk menentukan lokasi penelitian dengan menggunakan purposive sampling dan mengambil 35 responden terdiri 5 petani broiler dan 30 pedagang perantara dengan menggunakan purposive. Tabulasi data diperoleh dan dianalisis dengan memasarkan margin dan tingkat broiler pendapatan petani yang menguraikan secara deskriptif. Hasil penelitian menunjukkan bahwa saluran broiler pemasaran di Kota Kendari yang terlibat 4 jenis dengan dua lembaga pemasaran yang terlibat: pedagang pengumpul dan pedagang pengecer, bagian dari harga yang diterima petani broiler dari konsumen terakhir adalah 68,8\% sedangkan bagian dari harga yang diterima lembaga pemasaran adalah $31,2 \%$, marjin pemasaran pada harga broiler dari petani broiler ke konsumen terakhir adalah Rp.14.150 ekor-1 (penjualan broiler di tingkat peternak broiler adalah Rp.31.200 ekor-1, petani broiler untuk kolektor pedagang adalah Rp. 9.000 ekor-1 dan pedagang pengumpul ke pengecer adalah 5.150 ekor-1) dan tingkat pendapatan petani broiler di Kota Kendari itu Rp.17.046.139 siklus 1 atau Rp.5.013 ekor-1 cycle- 1 .
\end{abstract}

Kata kunci: Pemasaran, Pendapatan, Broiler, Pemasaran Margin 


\section{PENDAHULUAN}

Sub sektor peternakan merupakan bagian integral dari sektor pertanian yang berperan dalam menunjang pembangunan nasional. Salah satu komoditi pada subsektor peternakan yang dapat dikembangkan untuk memenuhi kebutuhan daging lokal adalah usaha ternak ayam broiler.

Data produksi ayam broiler di Provinsi Sulawesi Tenggara, khususnya Kota Kendari lima tahun terakhir menunjukkan kecenderungan meningkat. Pada tahun 2007-2011 terjadi peningkatan produksi, yakni tahun 2006 jumlah produksi ayam broiler sebesar 416.575 ekor danberdasarkan data tahun tahun 2010 mengalami kenaikan menjadi 467.194 ekor dengan rata-rata peningkatan pertahun hanya sebesar 3\% (BPS Sultra, 2012).

Upaya-upaya peningkatan produksi daging ayam broiler dengan perbaikan manajemen pola pemeliharaan menjadi tuntutan dalam memenuhi kebutuhan masyarakat yang semakin meningkat. Pada saat yang sama peningkatan produksi ayam broiler diharapkan mampu meningkatkan pendapatan peternak, mendorong diversifikasi pangan, dan memperbaiki mutu gizi masyarakat.

Proses penyaluran ternak oleh pedagang perantara melalui beberapa tahap distribusi sebelum sampai ke tangan konsumen akhir yaitu pengangkutan, pembayaran retribusi, bongkar dan muat ternak. Bila jarak antara peternak dengan konsumen dekat, maka biaya pengangkutan bisa diperkecil. Semakin jauh jarak dan semakin banyak perantara (lembaga pemasaran) yang terlibat dalam pemasaran, maka biaya pemasaran semakin tinggi.

Namun demikian, data dasar dan informasi mengenai potensi agribisnis ayam briler, dan besaran pendapatan peternak ayam broiler di Kota Kendari belum banyak diketahui dan belum tersedia secara optimal sehingga sangat penting dilakukan penelitian mengenai "PotensiAgribisnis Usahaternak Ayam Broiler di Kota Kendari”.

Tujuan yang ingin dicapai dalam penelitian ini adalah: (1) Mengidentifikasi kapasitas produksi pembudidaya ayam broiler dan saluran pemasaran ayam broiler di pasar lokal Kota Kendari. (2) Menganalisis bagian harga yang diterima oleh peternak dan lembaga pemasaran ayam broiler. (3) Menganalisis besarnya margin pemasaran ayam broiler ditingkat peternak, lembaga pemasaran dan konsumen. (4) Menganalisis besarnya pendapatan peternak ayam broiler di Kota Kendari.

Manfaat yang diharapkan dari penelitian ini adalah: (1) Bagi peternak, sebagai bahan informasi dan pertimbangan dalam menjalankan agribisnis usahaternak ayam broiler di di Kota Kendari. (2) Bagi pedagang perantara, sebagai bahan pertimbangan dalam upaya memasarkan ayam broiler di Kota Kendari. (3) Bagi pemerintah, sebagai bahan pertimbangan dalam menentukan kebijakan, terutama dalam meningkatkan produksi dan produktivitas serta perbaikan manajemen pola pemasaran ayam broiler di Kota Kendari.

\section{METODE PENELITIAN}

Penelitian ini dilaksanakan bulan Juli sampai Agustus 2012 dengan mengambil lokasi penelitian di Kota Kendari Provinsi Sulawesi Tenggara. Subyek penelitian meliputi: (1) Peternak yang memelihara ayam broiler di Kota Kendari baik peternak yang bermitra dengan perusahaan maupun tidak bermitra atau peternak mandiri. 2) Pedagang perantara yang ikut terlibat dalam pemasaran ternak ayam broiler seperti 
pedagang pengumpul dan pedagang pengecer di Kota Kendari.

Lokasi penelitian ditentukan secara purposive sampling mengingat Kota Kendari selain sebagai Ibukota Provinsi Sulawesi Tenggara juga merupakan pusat perekonomian sehingga potensial untuk memasarkan ayam broiler.

Subyek penelitian ini ditentukan secara purposive yang mewakili peternak produsen yang bermitra dengan perusahaan, peternak produsen yang tidak bermitra (usaha mandiri), berdasarkan keterwakilan jenis perusahaan mitra, lokasi usaha dan jumlah populasi ternak yang dimiliki.

Responden yang menjadi subyek penelitian sebanyak 35 orang responden yang terdiri dari 5 peternak produsen $(14,29 \%)$ dan 30 orang pedagang perantara $(85,71 \%)$. Peternak produsen ada 5 peternak produsen yang terdiri dari 4 peternak produsen yang bermitra dengan perusahaan dan 1 peternak produsen tidak bermitra dengan perusahaan (usaha mandiri).

Pedagang perantara sebanyak 30 orang yang terdiri dari 10 orang pedagang pengumpul (masing-masing pasar diwakili 2 orang) dan 20 orang pedagang pengecer (masing-masing pasar diwakili 4 orang) terdiri dari 5 lokasi pasar yang ada di Kota Kendari. Lokasi pasar yang dimaksud adalah 2 lokasi pasar modern (Pasar Basah Mall Mandonga dan Pedis Market) dan 3 lokasi pasar tradisional (Pasar Anduonohu, Pasar Panjang dan Pasar Baruga).

Perusahaan mitra peternak produsen yang menjadi obyek penelitian tersebut adalah: 1) Perusahaan Bintang Sejahtera Bersama (BSB) berlokasi di Kecamatan Baruga, 2) Perusahaan Ciomas Adisatwa di Kecamatan Baruga dan Kecamatan Poasia, dan 3) Perusahaan Inti Tani berlokasi di Kecamatan Puuwatu.
Penelusuran data tentang kapasitas produksi dan spot-spot pembudidaya ayam broiler (peternak produsen)yang ada di Kota Kendari serta mata rantai saluran pemasaran mulai tingkat peternak produsen sampai ke konsumen akhir akandianalisis dan dijelaskan secara deskriptif (tujuan pertama).

Data untuk mengetahui besarnya bagian harga yang diterima peternak dari harga yang dibayar konsumen (tujuan ke-2), dianalisis dengan menggunakan model menurut Sudiyono (2004); Saliem, (2004) sebagai berikut:

SP $(\%)=\frac{\text { Pf }}{\text { Pr }} \times 100 \%$

dengan:

$\mathrm{SP}=$ Besarnya bagian harga yang diterima peternak yang dinyatakan dengan persentase

$\mathrm{P}_{\mathrm{f}}=$ Harga ditingkat peternak $\left(\right.$ Rpekor $\left.^{-1}\right)$

$\mathrm{Pr}=$ Harga ditingkat konsumen $\left(\right.$ Rp ekor $\left.^{-1}\right)$

Margin pemasaran ternak ayam broiler di Kota Kendari sebagaimana tujuan ke-3 penelitian ini akan di analisis dengan rumus:

$\mathbf{M}=\mathbf{P r}-\mathbf{P}_{\mathrm{f}}$

dengan:

$\mathrm{M}=$ Margin pemasaran $\left(\mathrm{Rp} \mathrm{ekor}^{-1}\right)$

$\operatorname{Pr}=$ Harga di tingkat konsumen $\left(\mathrm{Rp}\right.$ ekor $^{-}$ 1)

$\mathrm{P}_{\mathrm{f}}=$ Harga di tingkat peternak $\left(\right.$ Rp ekor $\left.{ }^{-1}\right)$.

Sedangkan untuk mengetahui besarnya pendapatan peternak ayam broiler di Kota Kendari (tujuan ke-4), dianalisis dengan menggunakan model menurut Soekartawi (2005); Suratiyah (2005):

TPd = TPn $-\mathbf{T B}$.

dengan:

$\mathrm{TPd}=$ Total pendapatan $(\mathrm{Rp})$

TPn =Total penerimaan dari penjualan ayam broiler $(\mathrm{Rp})$

$\mathrm{TB}=$ Total biaya produksi dan pemasaran ayam broiler ( $\mathrm{Rp})$ 


\section{HASIL DAN PEMBAHASAN}

A. PotensiAgribisnis Ayam Broiler

1. Saluran dan Lembaga pemasaran ayam broiler

Berdasarkan hasil penelitian teridentifikasi bahwa saluran pemasaran ayam broiler di Kota Kendari terdiri dari empat tipe, yaitu: (1) Peternak $\rightarrow$ pedagang pengumpul $\rightarrow$ pedagang pengecer $\rightarrow$ konsumen akhir.

Peternak $\rightarrow$ pedagang pengumpul $\rightarrow$ konsumen akhir. (3) Peternak $\rightarrow$ pedagang pengecer $\rightarrow$ konsumen akhir. (4) Peternak $\rightarrow$ konsumen akhir.

Hal ini menggambarkan bahwa pada saluran 1, 2 dan 3 kurang efisien. Sedangkan saluran pemasaran pada tingkat 4 terlihat bahwa relatif lebih efisien. Pada tahap ini, ternak ayam broiler yang didistribusikan ke konsumen tidak membutuhkan perantara sehingga biaya yang dibutuhkan cenderung rendah yang ditanggung oleh konsumen sendiri.Adanya perbedaan tipe saluran pemasaran dan panjang pendeknya saluran pemasaran ini mempengaruhi biaya, harga, keuntungan dan margin pemasaran setiap pelaku pemasaran ayam broiler di Kota Kendari.

Hasil penelitian menunjukkan bahwa lembaga pemasaran yang terlibat dalam pemasaran ayam broiler di Kota Kendari terdiri dari pedagang pengumpul dan pedagang pengecer. Menurut Daniel (2002) pemasaran yang efisien akan mampu; (1) menyampaikan hasil-hasil dari produsen ke konsumen dengan biaya yang serendah-rendahnya, (2) mampu mengadakan pembagian yang adil dari keseluruhan harga yang dibayar konsumen terakhir kepada semua pihak yang ikut serta dalam kegiatan produksi dan pemasaran barang tersebut.Swastha (2002) menyatakan bahwa setiap perantara yang melakukan usaha menyalurkan barang kepada pembeli akhir membentuk tingkatan saluran pemasaran.

\section{Biaya pemasaran}

Biaya yang dikeluarkan meliputi biaya transportasi, upah tenaga kerja dan retribusi. Biaya yang dikeluarkan pedagang pengumpul setiap bulan dalam upaya memasarkan ayam broiler, meliputi biaya transportasi antara Rp.1.000.0000Rp.2.000.000, gaji tenaga kerja berkisar antara Rp.1.000.000-Rp.1.500.000 dan biaya retribusi Rp.100.000-Rp.150.000 dengan rata-rata jumlah ayam broiler yang dipasarkan sebanyak 2.490 ekor setiap bulannya.

Biaya transportasi yang dikeluarkan relatif banyak karena pedagang membeli ayam broiler selain di Kota Kendari, juga dari Kabupaten Konawe dan Kabupaten Konawe Selatan sehingga biaya yang dikeluarkanpun relatif besar. Biaya yang tidak kalah besarnya adalah gaji tenaga kerja untuk bongkar dan muat ternak karena setiap pedagang pengumpul memiliki 2-3 karyawan.

\section{Struktur harga ayam broiler ditingkat pedagang pengumpul}

Rata-rata harga pembelian ayam broiler oleh pedagang pengumpul dari peternak produsen yaitu sebesar Rp.31.200 ekor $^{-1}$ dan harga jual ayam broiler dari pedagang pengumpul ke pedagang pengecer yaitu sebesar Rp.40.200 ekor ${ }^{-1}$. Oleh karena itu rata-rata margin harga ayam broiler dari peternak produsen ke pedagang pengumpul adalah Rp.9.000 ekor ${ }^{-1}$. 
Tabel 1. Rata-rata Harga PemasaranAyam Broiler Ditingkat Pedagang Pengumpul di Pasar Lokal Kota Kendari

\begin{tabular}{lllll}
\hline \multirow{2}{*}{$\begin{array}{l}\text { No } \\
\text { Responden }\end{array}$} & \multirow{2}{*}{$\begin{array}{l}\text { Skala usaha } \\
\text { (ekor/siklus) }\end{array}$} & Pemasaran ayam broiler $\left(\right.$ Rp ekor $\left.^{-1}\right)$ & \\
\cline { 3 - 4 } & 2.500 & 32.000 & Harga jual & \\
\hline 1 & 4.000 & 32.000 & 41.000 & $1,3,4$ \\
3 & 1.700 & 30.000 & 40.000 & $1,4,5$ \\
4 & 3.200 & 32.000 & 40.000 & $1,3,4$ \\
5 & 1.500 & 33.000 & 40.000 & $1,3,4$ \\
6 & 2.100 & 32.000 & 42.000 & 4,5 \\
7 & 2.000 & 30.000 & 42.000 & $3,4,5$ \\
8 & 2.400 & 26.000 & 41.000 & 4,5 \\
9 & 2.500 & 33.000 & 32.000 & 1,2 \\
10 & 3.000 & 32.000 & 42.000 & $1,2,4$ \\
\hline Jumlah & 24.900 & 312.000 & 42.000 & $1,3,5$ \\
\hline Rata-rata & 2.490 & 31.200 & 402.000 & - \\
\hline Ket & & & 40.200 & - \\
\hline
\end{tabular}

Ket $^{(*)}$ : 1) Pasar Modern Mall Mandonga, 2) Pasar Modern Pedis Market, 3) Pasar Anduonohu, 4) Pasar Panjang, 5) Pasar Baruga.

Tabel 1 menunjukkan bahwa harga ayam broiler terendah yang dibeli oleh pedagang pengumpul dari peternak perodusen yaitu sebesar Rp.26.000 ekor ${ }^{-1}$ dari peternak produsen yang tidak bermitra dengan perusahaan yaitu usaha "Unggas Mandiri". Sebaliknya harga ayam broiler tertinggi yang dibeli oleh pedagang pengumpul dari peternak produsen yaitu sebesar Rp.33.000 ekor ${ }^{-1}$ yang bermitra dengan perusahaan Ciomas Adisatwa.

Perbedaan harga beli atau harga jual ayam broiler dari pedagang pengumpul ke pedagang pengecer adalah lama pembesaran ayam broiler sampai panen masing-masing berbeda-beda yaitu antara 25-35 hari per siklus produksi sehingga bobot badan ayam juga cenderung berbeda.

Hasil penelitian menggambarkan bahwa tempat pemasaran ayam broiler yang paling menguntungkan bagi pedagang pengumpul diantara 5 pasar lokal di Kota Kendari adalah Pasar Baruga karena harga penjualan di pasar tersebut relatif mahal yakni Rp.41.250 ekor ${ }^{-1}$ dibandingkan 4 pasar lokal lainnya. Hal ini disebabkan ayam yang diperjual belikan hanya sebatas ayam broiler dan jumlah pedagang pengecer di pasar tersebut relatif sedikit sehingga menyebabkan persaingan harga relatif rendah.

\section{Struktur harga ayam broiler ditingkat pedagang pengecer}

Berdasarkan hasil penelitian di 5 pasar lokal Kota Kendari bahwa rata-rata harga pembelian ayam broiler oleh pedagang pengecer dari pedagang pengumpul yaitu sebesar Rp.40.200 ekor ${ }^{-1}$ dan rata-rata harga penjualan ayam broiler oleh pedagang pengecer ke konsumen akhir sebesar Rp.45.350 ekor $^{-1}$. Rata-rata margin harga ayam dari pedagang pengecer ke konsumen akhir sebesar Rp.5.150 ekor ${ }^{-1}$. 
Tabel 2. Rata-rata Harga Pemasaran Ayam Broiler Ditingkat Pedagang Pengecer di Pasar Lokal Kota Kendari

\begin{tabular}{|c|c|c|c|c|c|c|}
\hline \multirow[b]{2}{*}{ Struktur harga } & \multicolumn{5}{|c|}{ Nama pasar lokal } & \multirow[b]{2}{*}{$\begin{array}{l}\text { Rata- } \\
\text { rata }\end{array}$} \\
\hline & $\begin{array}{l}\text { Mall } \\
\text { Mandonga }\end{array}$ & $\begin{array}{l}\text { Pedis } \\
\text { Market }\end{array}$ & $\begin{array}{l}\text { Pasar } \\
\text { Andounohu }\end{array}$ & $\begin{array}{l}\text { Pasar } \\
\text { Paniang }\end{array}$ & $\begin{array}{l}\text { Pasar } \\
\text { Baruga }\end{array}$ & \\
\hline Harga beli (Rp ekor $\left.{ }^{-1}\right)$ & 38.250 & 40.500 & 40.000 & 41.000 & 41.250 & 40.200 \\
\hline Harga jual (Rp ekor $\left.{ }^{-1}\right)$ & 43.000 & 45.000 & 46.750 & 45.500 & 46.500 & 45.350 \\
\hline
\end{tabular}

Tabel 2 menunjukkan harga pembelian ayam broiler terendah yaitu di Pasar Mall Mandonga (Rp.38.250 ekor ${ }^{-1}$ ) dan tertinggi di Pasar Baruga (Rp.41.250 ekor $^{-1}$ ). Sedangkan harga penjualan ayam broiler terendah yaitu di Pasar Mall Mandonga, yaitu Rp.43.000 ekor ${ }^{-1}$. Hal ini disebabkan banyak pedagang pengecer yang menjual ayam broiler beku berasal dari Provinsi Sulawesi Selatan dan ayam yang dijual di pasar tersebut cukup bervariasi yaitu ayam kampung, ayam petelur afkir dan ayam broiler menyebabkan persaingan harga relatif tinggi. Sebaliknya harga jual ayam tertinggi yaitu di Pasar Anduonohu adalah sebesar Rp.46.750 ekor ${ }^{-1}$, disebabkan pedagang pengecer ayam broiler di pasar tersebut sedikit sehingga menyebabkan persaingan harga relatif rendah.

\section{Bagian Harga dan Margin Pemasaran}

Bagian harga ayam broiler yang diterima peternak sekitar 68,8\%, sedangkan bagian harga yang diterima pedagang pengumpul 19,8\% dan bagian harga yang diterima pedagang pengecer hanya $11,4 \%$.

Tabel 3 menunjukkan rata-rata harga jual ayam broiler ditingkat peternak Rp.31.200 ekor ${ }^{-1}$. Margin pemasaran ayam broiler dari peternak ke pedagang pengumpul yaitu sebesar Rp.9.000 ekor ${ }^{-1}$, margin pemasaran dari pedagang pengumpul ke pedagang pengecer Rp.5.150 ekor ${ }^{-1}$, sedangkan margin pemasaran dari peternak ke pedagang pengecer (konsumen akhir) relatif tinggi yaitu sebesar Rp.14.150 ekor ${ }^{-1}$.

Faktor yang menyebabkan tinggi rendahnya margin pemasaran ayam broiler ditingkat peternak sampai ke konsumen akhir adalah panjangnya rantai pemasaran dan besarnya biaya yang dikeluarkan oleh masing-masing lembaga pemasaran (pedagang pengumpul dan pedagang pengecer).

Tabel 3. Margin pemasaran ayam broiler di lokasi penelitian

\begin{tabular}{|c|c|c|c|c|c|c|c|}
\hline \multirow{2}{*}{ Lembaga pemasaran } & \multirow{2}{*}{$\begin{array}{l}\text { Rata-rata } \\
\text { harga beli } \\
\left(\text { Rp ekor }^{-1}\right)\end{array}$} & \multirow{2}{*}{$\begin{array}{l}\text { Rata-rata } \\
\text { harga jual } \\
\left(\text { Rp ekor }^{-1}\right)\end{array}$} & \multicolumn{5}{|c|}{$\begin{array}{l}\text { Rata-rata harga jual ayam broiler di pasar } \\
\left(\text { Rp ekor }^{-1}\right)\end{array}$} \\
\hline & & & $\mathrm{MM}$ & PM & PA & PP & PB \\
\hline Peternak & - & 31.200 & - & - & - & - & - \\
\hline Pedagang Pengumpul & 31.200 & 40.200 & 38.250 & 40.500 & 40.000 & 41.000 & 41.250 \\
\hline Pedagang Pengecer & 40.200 & 45.350 & 43.000 & 45.000 & 46.750 & 45.500 & 46.500 \\
\hline
\end{tabular}


Analisis usaha ayam broiler

Gusasi dan Saade (2006), menyatakan besarnya jumlah ternak ayam pedaging yang dipelihara menentukan besarnya pendapatan dan keuntungan pelaku usaha peternakan ayam pedaging, yang skala usahanya semakin besar maka tingkat pendapatan dan efisiensi semakin tinggi. Rata-rata produksi produksi ayam broiler di Kota Kendari dapat dilihat pada Tabel 4.

Tabel 4 menunjukkan bahwa ratarata produksi usaha ayam broiler yaitu 3.400 ekor siklus ${ }^{-1}$. Produksi usaha ternak ayam broiler terendah yaitu peternak yang bermitra dengan perusahaan Inti Tani dengan rat-rata produksi 2.500 ekor siklus $^{-1}$ dan tertinggi yaitu peternak yang bermitra dengan perusahaan Ciomas Adisatwa dan peternak yang tidak bermitra (Unggas
Mandiri) masing-masing memproduksi 4.000 ekor siklus ${ }^{-1}$. Rata-rata lama pembesaran ayam broiler oleh peternak di Kota Kendari antara 25-35 hari siklus ${ }^{-}$ ${ }^{1}$ dan rata-rata siklus produksi 6-7 kali per tahun.

\section{Biaya produksi}

Biaya yang dikeluarkan oleh peternak ayam broiler meliputi biaya kebutuhan sarana produksi seperti pembelian bibit (DOC), pakan, obatobatan, vaksin, penyusutan peralatan, penyusutan kandang, gaji tenaga kerja, rekening listrik, transportasi dan lainlain. Biaya produksi yang dimaksudkan dalam penelitian ini adalah nilai keseluruhan input yang digunakan oleh peternak dalam usaha ternaknya selama satu siklus produksi.

Tabel 4. Rata-Rata Skala Usaha dan Siklus Produksi Ayam Broiler Kota Kendari

\begin{tabular}{|c|c|c|c|}
\hline $\begin{array}{l}\text { Produsen berdasarkan } \\
\text { lokasi kecamatan }\end{array}$ & $\begin{array}{l}\text { Skala usaha } \\
\text { (ekor/siklus) }\end{array}$ & $\begin{array}{l}\text { Siklus produksi } \\
\text { (hari) }\end{array}$ & $\begin{array}{l}\text { Lama produksi } \\
\text { (siklus/tahun) }\end{array}$ \\
\hline Baruga $^{(1)}$ & 3.500 & 33 & 6 \\
\hline Poasia ${ }^{(1)}$ & 4.000 & 35 & 7 \\
\hline Baruga $^{(2)}$ & 3.000 & 32 & 7 \\
\hline Puuwatu ${ }^{(3)}$ & 2.500 & 32 & 6 \\
\hline Baruga $^{(4)}$ & 4.000 & 25 & 7 \\
\hline Jumlah & 17.000 & - & - \\
\hline Rata-rata & 3.400 & - & - \\
\hline
\end{tabular}


Tabel 5. Biaya Produksi Usahaternak Ayam Broiler

\begin{tabular}{|c|c|c|c|c|c|c|}
\hline \multirow[b]{2}{*}{ Jenis biaya } & \multicolumn{6}{|c|}{ Kecamatan lokasiusaha (Rp) } \\
\hline & Baruga $^{(1)}$ & Poasia $^{(1)}$ & Baruga $^{(2)}$ & Puuwatu $^{(3)}$ & Baruga $^{(4)}$ & Jumlah \\
\hline \multicolumn{7}{|l|}{ Biaya variabel: } \\
\hline -Pembelian bibit & 21.000 .000 & 24.000 .000 & 17.400 .000 & 14.750 .000 & 24.000 .000 & 101.150 .000 \\
\hline -Pembelian pakan & 72.640 .000 & 79.380 .000 & 63.630 .000 & 47.565 .000 & 48.000 .000 & 311.215 .000 \\
\hline $\begin{array}{l}\text {-Pembelian vaksin } \\
\text { dan obat-obatan }\end{array}$ & 195.000 & 340.000 & 260.000 & 178.000 & 400.000 & 1.373 .000 \\
\hline \multicolumn{7}{|l|}{ Biaya tetap: } \\
\hline -Tenaga kerja & 1.900 .000 & 2.000 .000 & - & 1.600 .000 & 2.400 .000 & 7.900 .000 \\
\hline -Listrik & 235.000 & 980.000 & 250.000 & 215.000 & 270.000 & 1.950 .000 \\
\hline -Transportasi & 100.000 & 175.000 & 150.000 & 100.000 & 450.000 & 975.000 \\
\hline \multicolumn{7}{|l|}{-Penyusutan: } \\
\hline -T.pakan & 14.666 & 18.333 & 9.900 & 11.000 & 11.466 & 65.366 \\
\hline -T.minum & 11.466 & 43.333 & 7.740 & 8.600 & 11.466 & 82.606 \\
\hline -Kandang & 216.666 & 233.333 & 156.666 & 173.333 & 133.333 & 913333 \\
\hline Total biaya & 96.312 .800 & 108.889 .999 & 81.864 .306 & 64.600 .933 & 75.676 .266 & 416.024 .306 \\
\hline Rata-rata & - & - & - & - & - & 83.204 .861 \\
\hline
\end{tabular}

Tabel 5 menunjukkan bahwa ratarata biaya produksi yang dikeluarkan oleh peternak di Kota Kendari yaitu sebesar Rp.83.204.861 siklus ${ }^{-1}$ atau rata-rata biaya produksi untuk satu ekor ayam broiler selama satu siklus periode pembesaran adalah Rp.24.472.

Penggunaan biaya produksi terendah adalah peternak yang bermitra dengan Perusahaan Inti Tani di Kecamatan Puuwatu dengan total biaya Rp.64.600.933 siklus ${ }^{-1}$, artinya besarnya biaya produksi untuk satu ekor ayam adalah Rp.25.840 siklus $^{-1}$. Hal ini disebabkan jumlah produksi ayam broiler yang dikelola relatif sedikit yaitu hanya 2.500 ekor siklus ${ }^{-1}$ sehingga cenderung tidak mengeluarkan biaya operasional yang besar dengan rata-rata siklus produksi 35 hari. Selain itu, pola pengelolaan ternak ayam broiler di Perusahaan Inti Tani relatif lebih baik dengan pengalaman beternak dan bermitra relatif lebih lama dibandingkan peternak produsen lainnya. Cahyono (2002) menyatakan pula bahwa peningkatan budidaya ayam broiler sangat tergantung biaya oerasional usaha, siklus produksi dan pemasaran.

Penggunaan biaya tertinggi adalah peternak yang bermitra dengan perusahaan Ciomas Adisatwa di Kecamatan Poasia dengan total biaya sebesar Rp.108.889.999 siklus $^{-1}$, artinya biaya produksi untuk pemeliharaan satu ekor ayam broiler adalah Rp.27.222 siklus $^{-1}$. Hal ini disebabkan jumlah produksi ayam broiler relatif banyak 
yaitu mencapai 4.000 ekor siklus ${ }^{-1}$. Besarnya biaya pakan, bibit, tenaga kerja dan biaya listrik memungkinkan peternak mitra mengeluarkan biaya yang besar, selain rata-rata siklus produksi yang relatif lama yaitu 35 hari dengan pengalaman beternak dan bermitra baru 1,5 tahun.

\section{Penerimaan}

Penerimaan adalah hasil perkalian antara sejumlah input produksi dengan satuan harga yang berlaku di pasar. Penerimaan yang dimaksudkan dalam penelitian ini adalah hasil perkalian antara jumlah produksi ayam broiler dengan harga yang berlaku di lokasi penelitian.

Tabel 6 menunjukkan bahwa secara umum rata-rata penerimaan peternak ayam broiler di lokasi penelitian sebesar Rp.102.515.000 siklus ${ }^{-1}$ dengan rata-rata penerimaan untuk pembesaran satu ekor ayam broiler adalah Rp.30.151 siklus $^{-1}$.

Penerimaan terendah yaitu peternak yang bermitra dengan perusahaan Inti
Tani sebesar Rp.75.450.000 siklus ${ }^{-1}$ dan penerimaan untuk pembesaran satu ekor ayam broiler adalah Rp.30.180 siklus ${ }^{-1}$. Hal ini disebabkan jumlah produksi ayam broiler yang dikelola relatif sedikit yaitu hanya 2.500 ekor dan minimnya penjualan pupuk dari usaha ternak ayam broiler tersebut. Penerimaan tertinggi yaitu peternak produsen yang bermitra dengan perusahaan Ciomas Adisatwa sebesar Rp.128.720.000 siklus ${ }^{-1}$. Penerimaan untuk pembesaran satu ekor ayam broiler adalah Rp.32.180 siklus $^{-1}$.

\section{Pendapatan}

Pendapatan merupakan hasil bersih yang diperoleh setelah penerimaan dikurangi dengan biaya produksi yang dinyatakan dalam rupiah. Pendapatan yang dimaksud dalam penelitian ini adalah sejumlah uang yang diterima peternak responden setelah total penerimaan dikurangi dengan total pengeluaran (biaya) dalam satu siklus panen.

Tabel 6. Penerimaan Usahaternak Ayam Broiler di Kota Kendari

\begin{tabular}{|c|c|c|c|c|}
\hline \multirow{2}{*}{$\begin{array}{l}\text { Produsen } \\
\text { berdasarkan } \\
\text { kecamatan }\end{array}$} & \multirow{2}{*}{ lokasi } & \multicolumn{2}{|c|}{ Uraian penerimaan (Rp siklus $\left.{ }^{-1}\right)$} & \multirow{2}{*}{$\begin{array}{l}\text { Total } \\
\text { Penerimaan(Rp) }\end{array}$} \\
\hline & & Ayam Broiler & Pupuk & \\
\hline Baruga $^{(1)}$ & & 112.000 .000 & 525.000 & 112.525 .000 \\
\hline Poasia $^{(1)}$ & & 128.000 .000 & 720.000 & 128.720 .000 \\
\hline Baruga $^{(2)}$ & & 90.000 .000 & 630.000 & 90.630 .000 \\
\hline Puuwatu $^{(3)}$ & & 75.000 .000 & 450.000 & 75.450 .000 \\
\hline Baruga $^{(4)}$ & & 104.000 .000 & 1.250 .000 & 105.250 .000 \\
\hline Jumlah & & 509.000 .000 & 3.575 .000 & 512.575 .000 \\
\hline Rata-rata & & 101.800 .000 & 715.000 & 102.515 .000 \\
\hline
\end{tabular}


Tabel 7. Pendapatan Hasil Usahaternak Ayam Broiler Peternak di Kota Kendari

\begin{tabular}{|c|c|c|c|c|c|}
\hline \multirow{2}{*}{$\begin{array}{l}\text { Produsen } \\
\text { berdasarkan } \\
\text { kecamatan }\end{array}$} & \multirow[t]{2}{*}{ lokasi } & \multirow{2}{*}{$\begin{array}{l}\text { Skala usaha } \\
\text { (ekor/siklus) }\end{array}$} & \multicolumn{2}{|c|}{$\begin{array}{l}\text { Uraian pendapatan } \\
\left(\text { Rp siklus }^{-1}\right)\end{array}$} & \multirow{2}{*}{$\begin{array}{l}\text { Total pendapatan } \\
\text { (Rp) }\end{array}$} \\
\hline & & & Penerimaan & Biaya & \\
\hline Baruga $^{(1)}$ & & 3.500 & 112.525 .000 & 96.312 .800 & 16.212 .200 \\
\hline Poasia $^{(1)}$ & & 4.000 & 128.720 .000 & 108.889 .999 & 19.830 .001 \\
\hline Baruga $^{(2)}$ & & 3.000 & 90.630 .000 & 81.864 .306 & 8.765 .694 \\
\hline Puuwatu $^{(3)}$ & & 2.500 & 75.450 .000 & 64.600 .933 & 10.849 .067 \\
\hline Baruga $^{(4)}$ & & 4.000 & 105.250 .000 & 75.676 .266 & 29.573 .734 \\
\hline Jumlah & & 17.000 & 512.575 .000 & 427.344 .304 & 85.230 .696 \\
\hline Rata-rata & & 3.400 & 102.515 .000 & 85.468 .861 & 17.046.139 \\
\hline
\end{tabular}

Tabel 7 menunjukkan bahwa secara umum rata-rata pendapatan peternak ayam broiler di Kota Kendari yaitu sebesar Rp.17.046.139 siklus $^{-1}$ dengan rata-rata umum pendapatan untuk pembesaran satu ekor ayam broiler adalah Rp.5.013 siklus $^{-1}$.

Pendapatan terendah adalah peternak produsen yang bermitra dengan perusahaan Bintang Sejahtera Bersama sebesar Rp.8.765.694 siklus ${ }^{-1}$. Pendapatan untuk pembesaran satu ekor ayam broiler adalah Rp.2.921 siklus $^{-1}$. Hal ini disebabkan jumlah ayam broiler yang dikelola relatif kecil yaitu 3.000 ekor siklus ${ }^{-1}$ dan biaya produksi relatif besar yaitu pembelian pakan dan pembelian bibit sehingga memungkinkan pendapatan yang diterima juga relatif kecil.

Pendapatan tertinggi yaitu peternak produsen yang tidak bermitra dengan perusahaan (Unggas Mandiri) sebesar Rp.29.573.734 siklus ${ }^{-1}$. Pendapatan yang diperoleh untuk pembesaran satu ekor ayam broiler adalah Rp.7.393 siklus $^{-1}$. Hal ini disebabkan jumlah produksi ayam broiler yang dikelola relatif banyak yaitu 4.000 ekor siklus ${ }^{-1}$, biaya produksi relatif rendah karena masa pembesaran hanya 25 hari serta berpengalaman memelihara ayam broiler sudah 5 tahun sehingga memungkinkan peternak non kemitraan memperoleh pendapatan yang relatif besar.Purwanto (1999) menyatakan pula bahwa tingkat pendapatan yang diperoleh peternak plasma ayam pedaging akan semakin meningkat seiring dengan peningkatan jumlah ternak ayam pedaging.

\section{KESIMPULAN DAN SARAN}

Berdasarkan hasil penelitian maka dapat disimpulkan bahwa:

1. Rata-rata kapasitas produksi pembudidaya ayam broiler di Kota Kendari sebanyak 3.400 ekor setiap siklus produksi pembesaran.Saluran pemasaran terdiri dari 4 tipedan lembaga pemasaran yang terlibat adalah pedagang pengumpul dan pedagang pengecer.

2. Bagian harga yang diterima peternak dari sejumlah harga yang dibayar konsumen akhir adalah 68,8\%, sedangkan bagian harga yang diterima oleh lembaga pemasaran adalah $31,2 \%$.

3. Margin pemasaran ayam broiler dari harga tingkat peternak ke konsumen akhir adalah Rp.14.150 ekor ${ }^{-1}$ (harga jual ayam broiler ditingkat peternak adalah Rp.31.200 ekor ${ }^{-1}$, peternak ke 
pedagang pengumpul adalah Rp.9.000 ekor $^{-1}$ dan pedagang pengumpul ke pedagang pengecer adalah Rp.5.150 ekor $^{-1}$ ).

4. Besarnya pendapatan peternak ayam broiler di Kota Kendari adalah Rp.17.046.139 siklus $^{-1}$ atau Rp.5.013 ekor $^{-1}$ siklus $^{-1}$.

Disarankan kepada peternak produsen ayam broiler agar memperoleh pendapatan lebih besar dari Rp.5.013 ekor $^{-1}$ maka harus melakukan efisiensi biaya pakan dan upaya negosiasi bisnis dengan lembaga pemasaran untuk meningkatkan nilai penawaran harga jual ternak.

\section{DAFTAR PUSTAKA}

BPSSultra. 2012. Sulawesi Tenggara Dalam Angka. Badan Pusat Statistik Provinsi Sulawesi Tenggara. Kendari.

Cahyono, B. 2002. Cara Meningkatkan Budidaya ayam Ras Pedaging (Broiler). Yayasan Nusantara. Yogyakarta.

Daniel, M. 2002. Pengantar Ekonomi Pertanian. Buni Aksara. Jakarta.

Gusasi, A. dan M.A. Saade. 2006. Analisis Pendapatan dan Efisiensi Usaha Ternak Ayam Potong pada Usaha Skala Kecil. Available at http:www.stpp gowa.ac.id/hinght.download. jurnal/serisosek.Pdf. Accession date: 25 Juni 2011. (online). (Diakses pada tanggal 28 Novemberi 2012).

Isra, F. 2010. Analisis pendapatan dan kelayakan usaha ayam ras petelur pada peternakan Bina Unggas Kecamatan Poasia Kota Kendari. Skripsi. Jurusan Peternakan Fakultas Pertanian Universitas Haluoleo. Kendari.
Purwanto, A.D. 1999. Analisis profitabilitas peternak plasma ayam pedaging pada berbagai tingkat skala usaha melalui perusahaan kemitraan wilayah Kabupaten Tanggamus di Lampung. Tesis S-2. Fakultas Peternakan UGM. Yogyakarta. (online). (Diakses pada tanggal 28 Novemberi 2012).

Saliem, H. P. 2004. Analisis Margin Pemasaran: Salah satu pendekatan dalam sistem distribusi pangan. Dalam Prospek Usaha dan Pemasaran Beberapa Komoditas Pertanian. Monograph. Series No. 24. Pusat Penelitian dan Pengembangan Sosial Ekonomi Pertanian Bogor. Bogor.

Soekartawi. 2005. Ilmu Usahatani. PT Raja Grafindo Persada. Jakarta.

Sudiyono, A. 2004. Pemasaran Pertanian. Universitas Muhamadiyah. Malang.

Suratiyah. 2005. Ilmu Usahatani. Penebar Swadaya. Jakarta.

Swastha, B. 2002. Azas-Azas Marketing. Liberty. Yogyakarta. 